\title{
Effects of the Thai massage program on range of motion of lower extremities and vertical jump performance in collegiate volleyball players, Burapha Univeristy, Thailand
}

\author{
Sirikool Klumkool ${ }^{1,3^{*}}$, Kawiya Sintara', Sakesan Tongkhambancsong ${ }^{2}$ \\ From 4th Congress of the International Foot and Ankle Biomechanics (i-FAB) Community \\ Busan, Korea. 8-11 April 2014
}

Sport massage can enhance athletic physical performance which is similar to Thai traditional massage but no evidence reports the increase in athletic performance before competition. The purpose of this research was to study effects of the Thai massage program on range of motion (ROM) of lower extremities and vertical jump performance (VJP) in collegiate volleyball players. Twelve males and twelve females in collegiate volleyball, age between 18-22 years, were randomly divided into two groups; experimental $(\mathrm{N}=12)$ and control groups $(\mathrm{N}=12)$. All subjects were measured ROM including knee flexion, ankle plantarflexion and dorsiflexion, and VJP. Thai massage program was applied to the experimental group for 30 minutes and the control group sat still for 30 minutes. The post-test was done and the tests were repeatedly measured every other day for 3 days. The mean differences of the pre and post-test data were calculated and statistically analyzed by using repeatedly measured ANCOVA at the level of .05. The results showed that the mean difference of ROM of Lt. knee flexion, Rt. knee flexion, Lt. ankle plantarflexion, Rt. ankle plantarflexion, Lt. ankle dorsiflexion, and Rt. ankle dorsiflexion were significantly different between groups ( $p=.015, .002, .011, .004, .000$, and .000, respectively). Vertical jump performance was significantly different between groups $(p=.026)$. Thai massage program was able to increase ROM of the lower extremities and jump performance. Thai Massage was able to warm for improving performance in competition.

* Correspondence: AKEATM@hotmail.com

${ }^{1}$ Faculty of Sport Science, Burapha University, Thailand

Full list of author information is available at the end of the article
Authors' details

${ }^{1}$ Faculty of Sport Science, Burapha University, Thailand. ${ }^{2}$ Faculty of Education, Burapha University, Thailand. ${ }^{3}$ School of Health Science, Mae Fah Luang University, Thailand.

Published: 8 April 2014

doi:10.1186/1757-1146-7-S1-A44

Cite this article as: Klumkool et al.: Effects of the Thai massage program on range of motion of lower extremities and vertical jump performance in collegiate volleyball players, Burapha Univeristy, Thailand. Journal of Foot and Ankle Research 2014 7(Suppl 1):A44.

Submit your next manuscript to BioMed Central and take full advantage of:

- Convenient online submission

- Thorough peer review

- No space constraints or color figure charges

- Immediate publication on acceptance

- Inclusion in PubMed, CAS, Scopus and Google Scholar

- Research which is freely available for redistribution 